\title{
PENINGKATAN KOMPETENSI GURU MATEMATIKA MELALUI PELATIHAN PENGUATAN MATERI MATEMATIKA DI MADRASAH IBTIDIYAH SE-KECAMATAN JONGGAT LOMBOK TENGAH
}

\author{
Yandika Nugraha' ${ }^{1}$, Susilahuddin P. ${ }^{2}$, M. Syawahid ${ }^{3}$ \\ ${ }^{1}$ Tadris Matematika, Universitas Islam Negeri Mataram, yandika310189@yahoo.com \\ ${ }^{2}$ Tadris Matematika, Universitas Islam Negeri Mataram, susputrawangsa@gmail.com \\ ${ }^{3}$ Tadris Matematika, Universitas Islam Negeri Mataram, syawahid@gmail.com
}

\begin{abstract}
ABSTRAK
Abstrak: Pengadian ini bertujuan untuk meningkatkan kompetensi guru matematika melalui pelatihan penguatan materi matematika. Kegiatan pelatihan ini menggunakan pendekatan pelatihan active learning dimana narasumber hanya sebagai fasilitator dan lebih mengekplorasi kemampuan peserta dengan memberikan pendampingan dan mengeksplorasi terkait materi matematika dan penilaian hasil belajar. Adapun peserta kegiatan pelatihan yaitu terdiri dari guru-guru yang mengajar matematika dan berasal dari madrasah ibtidaiyah se-Kecamatan Jonggat dan merupakan bagian dari Kelompok Kerja Madrasah (KKM) MIN 2 Lombok Tengah. Pelaksanaan kegiatan pelatihan berjalan lancar tanpa ada kendala berarti dan sesuai dengan jadwal yang sudah direncanakan. Para peserta sangat antusias dalam menerima wawasan baru sebagai bentuk penyegaran terkait pemahaman materi matematika sebagai bentuk implementasi didalam pembelajaran di kelas.
\end{abstract}

Kata Kunci: Materi Matematika, Penilaian Hasil belajar, Madrasah Ibtidaiyah

\begin{abstract}
The current community service intends to enhance mathematics teacher competences through a training strengthening understanding of mathematics content. Active learning approach is applied as the training approach where the speaker tends to be a facilitator for the participants and to explore in order to expanding participants understanding of mathematics content and learning assessment. The participants of the training are mathematics teachers of Islamic primary schools all over Jonggat District where they are member of Islamic School Partnership of MIN 2 Central Lombok. The training run well and the participants are looked enthusiast in learning a recent paradigm of teaching mathematics that be implemented in their classroom.
\end{abstract}

Keywords: Mathematics Content; Learning Assessment; Islamic Primary School;

Riwayat Artikel: Diterima: 8-12-2017, Disetujui: 15-12-2017 


\section{A. LATAR BELAKANG}

Materi matematika pertama kali yang diperkenalkan pada saat awal pembelajaran di madrasah ibtidaiyah/sekolah dasar yaitu terkait bilangan. Tidak bisa dipungkiri bahwa materi bilangan sangatlah penting. Hal ini dikarenakan hampir seluruh konsep matematika dari jenjang pendidikan dasar sampai pendidikan tinggi selalu melibatkan bilangan. Pembelajaran pemahaman materi bilangan secara benar dan berkesinambungan dari awal pengenalan bilangan hingga aplikasi dari bilangan akan menjadikan siswa tidak lagi melihat matematika sebagai suatu masalah yang sematamata hanya menggunakan hafalan, rumus-rumus, maupun perhitungan algoritma (prosedural), tetapi menjadi suatu keterampilan khusus dalam memecahkan masalah matematika yang lainnya.

Diperlukan suatu pembelajaran dalam melihat suatu bilangan melalui cara pandang yang berbeda secaraluwes, akurat, dan efisien yang dapat mendorong proses berfikir kreatif, kritis, logis, serta sistematis peserta didik. Hal ini sesuai dengan PERMENDIKNAS No. 22 Tahun 2006 dimana menyebutkan bahwa salah satu tujuan pembelajaran di SD/MI yaitu Memahami konsep matematika, menjelaskan keterkaitan antarkonsep dan mengaplikasikan konsep atau algoritma, secara luwes, akurat, efisien, dan tepat, dalam pemecahan masalah serta menggunakan penalaran pada pola dan sifat, melakukan manipulasi matematika dalam membuat generalisasi, menyusun bukti, atau menjelaskan gagasan dan pernyataan matematika.

Untuk mengakomodasi hal tersebut, peserta didik perludiajarkan untuk pekaterhadap bilangansehingga peserta didik yang mempunyai kepekaan bilangan yang baik maka secara tidak langsung memiliki sifat luwes, percaya diri, dan mampu mengatasi berbagai macam pertanyaan yang berkaitan dengan bilangan dalam memecahkan masalah matematika. Merupakan tugas serta tanggung jawab tenaga kependidikan dalam hal ini adalah guru matematika sebagai salah satu unsur yang berperan penting didalam proses pembelajaran untuk meningkatkan keterampilan penguasaan bilangan peserta didik sehingga membuat peserta didik memiliki cara pandang yang berbeda dari melihat suatu bilangan dari berbagai macam materi matematika yang ada.

Oleh karena itu, melalui kegiatan Tri Dharma Perguruan Tinggi di UIN Mataram ini, pengabdi ingin memberikan pelatihan penguatan materi matematika untuk meningkatkan kompetensi guru matematika di madrasah ibtidaiyah, terutama se-Kecamatan Jonggat. Pelatihan adalah mengembangkan orang-orang sebagai individu dan mendorong mereka menjadi lebih percaya diri dan berkemampuan dalam hidup dan pekerjaannya [5]. Secara garis besar, pendidikan dan pelatihan (Diklat) dapat diartikan sebagai akuisisi dari pengetahuan (knowledge), keterampilan (skills), dan sikap (attitudes) yang memampukan manusia untuk mencapai tujuan individual dan organisasi saat ini dan di masa depan [3]. Adapun perspektif ahli lain menyatakan bahwa pelatihan adalah proses pembelajaran yang terkait dengan pekerjaan spesifik saat ini, proses desain, keahlian, dan teknis pekerjaan untuk mempertahankan dan meningkatkan efektifitas masing-masing individu dan kelompok dalam suatu organisasi [1]. Sehingga diharapkan akan memberikan perubahan guru menjadi lebih berkualitas. guru yang baik dan berkualitas adalah guru yang menguasai bahan ajar, mengajar dengan strategi dan teknik 
yang tepat, tahu bagaimana bersikap, memperlakukan atau berinteraksi dengan siswa, dan memahami kondisi siswa [9]. Selain itu, guru harus cermat dalam melakukan pembelajaran dan selalu merefleksi pembelajaran yang telah dilakukan, yaitu apa yang guru lakukan dan bagaimana dampak pembelajaran tersebut terhadap kemampuan sosial dan akademik siswa [2]. Jadi jelas bahwa seorang guru akan berhasil menciptakan pembelajaran yang berkualitas apabila menguasai materi ajar dengan baik, menggunakan strategi dan metode pembelajaran yang tepat, memahami psikologi pendidikan dengan baik, dan selalu merefleksi pembelajaran yang dilakukan. Guru seperti inilah yang mampu menciptakan pembelajaran yang efektif.

Adapun manfaat yang diharapkan dalam pengabdian ini yaitu: (1) Peningkatan pengetahuan serta keterampilan guru tentang pembelajaran matematika yang sesuai dengan kosep, konteks, dan kontennya sebagai upaya untuk menciptakan pembelajaran yang berkualitas. (2) Peningkatan pengetahuan serta keterampilan guru tentang cara pembuatan soal-soal matematika yang sesuai dengan kisi-kisi sebagai upaya untuk menciptakan penilaian hasil belajar yang berkualitas. (3) Membangun suasana semangat kerja sama serta solidaritas sesama guru yang lain dimana guru berperan aktif selama proses pelatihan berlangsung. (4) Peserta dapat menyerap ilmu yang didapat sehingga dapat diimplementasikan di madrasah tempat masing-masing bekerja. (5) Peserta mengalami peningkatan kompetensi dalam bidang matematika pada umumnya. (6) Guru-guru dapat mengaplikasikan pembelajaran yang didapat selama proses pelatihan. (7) Guru-guru yang berada di madrasah ibtidaiyah se-Kecamatan Jonggat dapat menularkan maupun berbagi info kepada guru-guru lainnya baik di madrasah masing-masing, maupun madrasah di luar Kecamatan Jonggat. (8) Dapat menjadi langkah awal dari program berkelanjutan sehingga dapat membina guru-guru terutama guru yang mengajar matematika baik dilokasi yang sama maupun dilokasi lainnya.

Adapun pihak-pihak yag terlibat dalam penelitian ini yaitu: (1) Pusat Pengabdian Kepada Masyarakat serta Lembaga Penelitian dan Pengabdian Kepada Masyarakat Universitas Islam Negeri Mataram sebagai perwakilan dari Kementerian Agama RI. (2) Kelompok Kerja Madrasah (KKM) se Kecamatan Jonggat. (3) Kepala sekolah MIN 2 Lombok Tengah selaku ketua KKM. (4) Guru-guru yang mengajar matematika di madrasah ibtidaiyah se-Kecamatan Jonggat. (5) Panitia pelaksana yaitu pengabdi beserta tim pelaksana.

Dalam kegiatan pelatihan ini, diperlukan strategi dan metode pengabdian antara lain: (1) Tahap Observasi, untuk mengamati kondisi riil pada madrasah dampingan untuk menemukan kebutuhan madrasah ataupun masalah yang dihadapi madrasah agar dapat diberikan solusi yang tepat oleh pengabdi. (2) Sosialisasi pentingnya pelatihan, dalam menentukan solusi yang akan diberikan pengabdi kepada madrasah binaan, sehingga perlu diadakan sosialisasi pentingnya pelatihan yang akan dilaksanakan di madrasah binaan tersebut. (3) Pelatihan diberikan kepada para guru untuk meningkatkan kapasitas dalam pembelajaran matematika. (4) Pendampingan, yang dilakukan setelah melaksanakan pelatihan sebagai tindak lanjut pengabdi untuk melihat sejauh mana keberlangsungan dan tingkat perkembangan madrasah binaan. 
Supaya kegiatan pelatihan dapat terlaksana dengan baik dan lancar, diperlukan sumberdaya yang ahli dibidangnya, adapun sumber daya pendukungnya adalah; (1) Pengabdi, sebagai fasilitator dalam pengabdian ini, pengabdi memiliki kemampuan dan pemahaman terkait suatu pembelajaran matematika dikarenakan latar belakang pengabdi sebagai salah satu dosen di Program Studi Tadris matematika UIN Mataram yang memiliki keahlian dibidang ilmu matematika dan pendidikan matematika di sekolah tingkat dasar sampai tingkat perguruan tinggi. Disamping mengajar di Program Studi Tadris Matematika, pengabdi juga mengajar di Program Studi PGMI sehingga mengetahui perkembangan keilmuan di tingkat madrasah ibtidaiyah. (2) Sumber daya manusia lainnya diluar pengabdi yang memiliki keahlian dibidang ilmu matematika dan pendidikan matematika dasar, dimana dalam hal ini berperan sebagai narasumber dalam memberikan pelatihan penguatan materi matematika untuk meningkatkan kompetensi guru Guru Matematika Se-Kecamatan Jonggat Lombok Tengah. (3) MIN 2 Lombok Tengah merupakan pendukung dalam hal sarana dan prasarana untuk mendukung berjalannya pembinaan sampai pendamingan yang berkelanjutan.

\section{B. METODE PELAKSANAAN}

Adapun kegiatan madrasah binaan ini terdiri dari beberapa tahapan yaitu:

\section{Observasi Awal}

Observasi awal dilaksanakan pada hari Sabtu, 15 April 2017 bertujuan untuk ajang silaturrahmi sekaligus untuk menyelaraskan informasi awal terkait permasalahan yang akan diangkat dalam pengabdian ada di lokasi berupa pembelajaran yang ada di KKM MIN 2 Lombok Tengah. Observasi berikutnya dilaksanakan untuk pendataan potensi yang dimiliki oleh subjek dampingan berupa data jumlah sekolah, jumlah guru yang hendak dijadikan peserta pelatihan. Pada tahap finalisasi ini sudah ditentukan bahwa peserta pelatihan berjumlah 20 orang yang tesebar di berbagai madrasah ibtidaiyah se Kecamatan Jonggat. Adapun penentuan dari peserta diserahkan langsung kepada Ketua KKM MIN 2 Lombok Tengah yang bertindak sebagai mitra dari pengabdi.

\section{Koordinasi dengan Narasumber dan Lokasi Kegiatan Pelatihan}

Metode yang digunakan dalam kegiatan ini adalah perpaduan antara ceramah, diskusi interaktif, tanya jawab, serta demonstrasi yang dilakukan antara narasumber dengan peserta. Peserta adalah subjek aktif dan narasumber berfungsi sebagai sumber belajar, fasilitator dan dinamisator. Kegiatan pengabdian yang dilaksanakan ini bekerjasama/berkolaborasi dengan yang ahli/penatar di bidang matematika sehingga pada pelaksanaannya saling berkolaborasidan bekerjasama baik dalam hal persiapan, pelaksanaan, maupun penyamian materi pelatihan. Untuk penyampaian materi pelatihan melibatkan kolaborasi antara dosen ahli di bidang matematika yang perna menempuh studi di Belanda yaitu Bapak Susilahuddin Putrawangsa dan Bapak Habibi Ratu Perwira Negara. Oleh karena itu, dengan adanya kolaborasi tersebut diharapkan dapat meningkatkan 
kualitas kegiatan pelatihan sehingga dapat berjalan efektif dan berkualitas.

Setelah sebelumnya mengetahui jumlah guru. Pada kegiatan berikutnya, yaitu persiapan kegiatan, dimana panitia pelaksana melakukan survey langsung ke lokasi kegiatan umtuk mempersiapkan secara maksimal baik dari materi pelatihan, dokumen, LCD, sound system, spanduk, maupun kesiapan ruangan. Adapun lokasi pelaksanaan kegiatan pelatihan yaitu di Madrasah Ibtidaiyah Negeri 2 Lombok Tengah.

\section{HASIL DAN PEMBAHASAN}

Kegiatan pelatihan penguatan materi matematika untuk meningkatkan kompetensi guru matematika Se-Kecamatan Jonggat Lombok Tengah berjalan lancar dan tanpa ada kendala. Kegiatan pelatihan ini dilaksanakan pada hari Sabtu tanggal 26 Agustus di MIN 2 Lombok tengah dengan peserta terdiri dari 20 orang guru. Kegiatan pelatihan ini dibagi menjadi 2 sesi dimana sesi pertama diisi oleh Bapak Sussilahuddin Putrawangsa M.S. dengan di moderator oleh Bapak Malik Ibrahim, M.Pd. Pada sesi pertama mengangkat materi yang terkait pemahaman konsep Matematika, terutama pada materi bilangan dmana pemahaman terkait bilangan mrupakan suatu pondasi dasar dari pembelajaran Matematika. Hal ini dikarenakan penggunaan konsep bilangan selalu ada dari awal pembelajaran Matematika dan seterusnya. Untuk itu diperlukan suatu metode atau alat baru dalam membelajarkan bilangan dengan cara dan konsep yang berbeda seperti menggunkan kepekaan terhadap bilangan. Sedangkan pada sesi kedua diisi oleh Bapak Habibi Ratu Perwira Negara, M.Pd. dengan di moderator oleh Bapak Malik Ibrahim, M.Pd. Pada sesi kedua, pemateri menjelaskan terkait menyusun alat penilaian untuk mengukur keberhasilan proses pembelajaran di kelas salah satunya yaitu menyusun soal yang sesuai dengan kompetensi dasar dari pembelajaran Matematika. Untuk itu harus diselaraskan antara soal dengan kisi-kisi maupun indikatornya.

Acara pelatihan ini merupakan kegiatan pengabdian Dosen UIN Mataram yang dinaungi oleh Lembaga Penelitian dan Pengabdian kepada Masyarakat (LP2M) UIN Mataram sebagai perwujudan dari salah satu Tri Dharma Dosen yaitu pengabdian. Sekitar pukul 07.00 Wita, panitia pelaksana bersama-sama dengan narasumber tiba di lokasi pelatihan. Sebelum menuju ruangan, kami disambut baik oleh pihak sekolah terutama ketua KKM sekaligus menjabat sebagai kepala sekolah MIN 2 Jonggat yaitu Bapak Abdul Fattah, M.Pd. Sebelum masuk pada kegiatan inti, terlebih dahulu kegiatan pelatihan diawali dengan sesi pembukaan. Pada kesempatan ini sambutan diberikan oleh pihak penyelenggara dan bapak ketua KKM yang sekaligus membuka kegiatan pelatihan secara resmi. Pada sambutannya, bapak ketua KKM sangat mangapresiasi kegiatan pelatihan yang diselenggarakan oleh pihak penyelenggara, yang pada kesempatan ini dilakukan oleh LP2M UIN Mataram. Kegiatan seperti ini diyakini dapat meningkatkan kualitas SDM terutama kompetensi guru dalam mengajar matematika di MI/SD. Acara pembukaan berlangsung kurang lebih selama 30 menit, setelah itu diselangi dengan coffee break 
sebelum dilanjutkan dengan acara inti yakni pemberian materi pelatihan oleh dua narasumber yang sudah hadir.

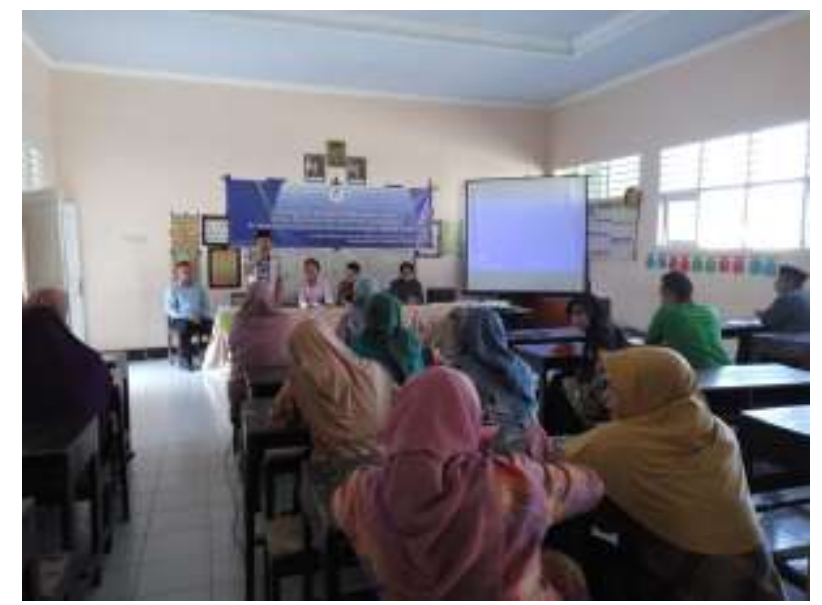

Gambar 1. Acara Pembukaan

Sekitar pukul 08.30 Wita acara inti dari kegiatan pelatihan dimulai, sebelum acara dimulai terlebih dahulu moderator membacakan Curriculum Vitae pemateri yang pada kesempatan ini dihadiri oleh bapak Susilahudin Putrawangsa, M.Sc selaku pemateri pertama dan bapak Habibi Ratu Perwira Negara, M.Pd selaku pemateri kedua. Setelah 10 menit berlalu, penyampaian materi oleh pemateri pertama berlangsung dengan seksama. Terlihat dari keseriusan peserta pelatihan yang mendengarkan penyampaian materi dengan tenang. Penyampaian materi berlangsung selama kurang lebih 120 menit, yang kemudian dilanjutkan dengan penyampaian pemateri kedua selama 120 menit. Antusiasme peserta semakin tinggi setelah mendengarkan penyampaian materi dari kedua pemateri, hal ini terlihat dari banyaknya pertanyaan yang diajukan oleh para peserta. Beberapa pertanyaan yang diajukan diantaranya pertanyaan terkait konsep dasar operasi bilangan bulat yang diajarkan ditingkat MI/SD. Dari penjelasan pemateri bahwa suatu pemahaman terhadap bilangan akan selalu dipegunakan dalam matematika. Siswa butuh suatu pemahaman dimana siswa tidak mudah menyerah dalam memcahkan masalah matematika. Selain itu, peserta juga mengajukan pertanyaan terkait bagaimana seorang guru matematika MI/SD mengajarkan matematika jika guru tersebut bukan baground pendidikan matematika. Hal ini menjadi semakin menarik perhatian bapak pemateri untuk memberikan jawaban yang tepat kepada peserta pelatihan. Pertanyaan terakhir disampaikan terkait evaluasi dan sistem penilaian guru matematika, baik dalam membuat soal evaluasi, kalimat operasional yang tepat, tingkat kesukaran soal dan sebagainya. Pada momen ini, pemateri memberikan pemahaman kata-kata operasional yang tepat untuk digunakan dalam pembuatan soal evaluasi, selain itu pemateri juga menyampaikan bahwa yang terpenting dalam evaluasi adalah kesesuaian antara indikator dengan soal evaluasi. Kegiatan pelatihan ditutup pada pukul 14.30 disertai serah terima sertifikat, konsumsi, dan akomodasi yang sebelumnya telah disiapkan oleh pantia. 


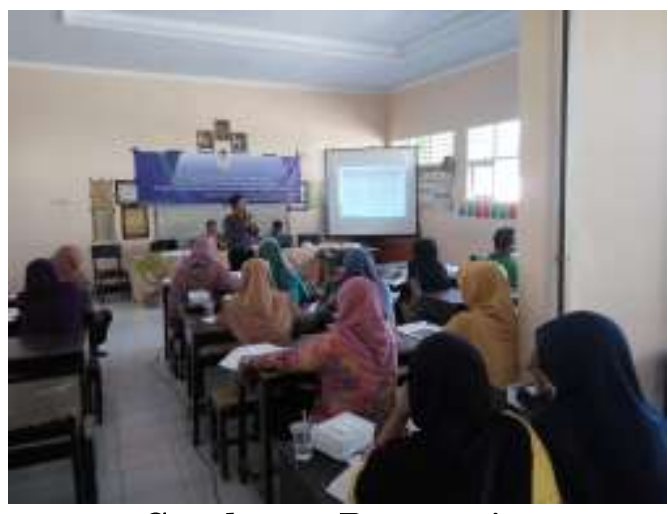

Gambar 2. Pemateri 2

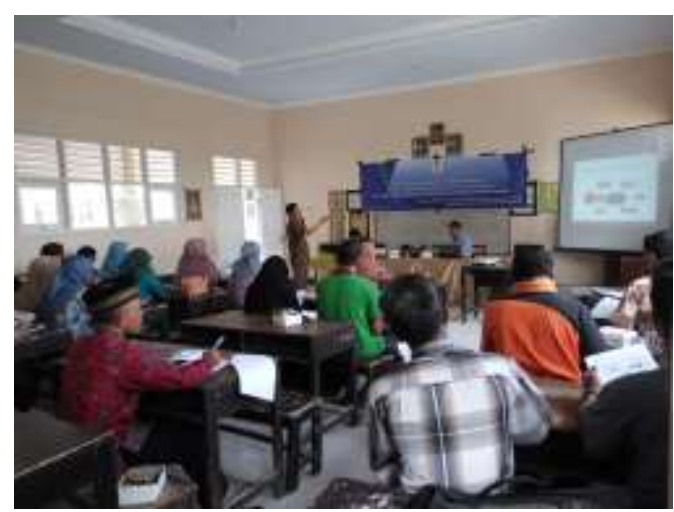

Gambar 3. Pemateri 3

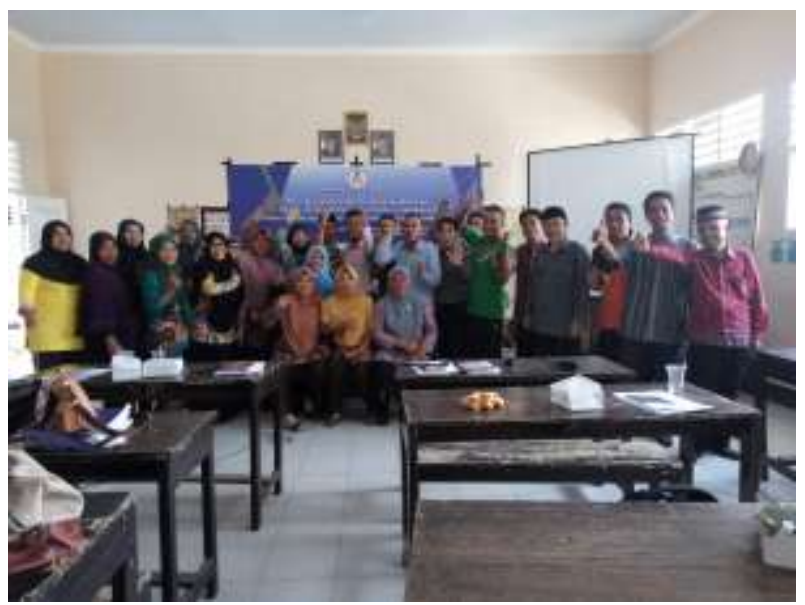

Gambar 4. Penutupan Bersama

\section{SIMPULAN DAN SARAN}

\section{Simpulan}

Sebagai akhir dari laporan kegiatan pengabdian madrasah binaan di madrasah ibtidaiyah se-Kecamatan Jonggat, didapatkan beberapa kesimpulan yaitu sebagai berikut:

a. Kegiatan pelatihan berjalan sesuai dengan yang dijadwalkan. Para peserta dapat langsung melihat materi melalui media LCD dan mempraktekkan apa yang disampaikan oleh narasumber sehingga peserta mengaplikasikan sewaktu pembelajaran di kelas.

b. Pelatihan penguatan materi matematika untuk meningkatkan kompetensi guru matematika Se-Kecamatan Jonggat Lombok Tengah ini berlangsung lancar dan tanpa ada hambatan berarti. Adapun suasana yang ada selama pelatihan sangat cair antara narasumber dan peserta pelatihan. Disamping itu, peserta juga sangat antusias dalam menjalani proses pelatihan.

\section{Saran}

Berdasarkan hasil kegiatan pelatihan, terdapat saran yang diberikan oleh berbagai pihak, yaitu:

a. Pengabdian ini tidak hanya sebatas pada pelatihan materi matematika, tetapi materi yang lain

b. Pengabdian dilaksanakan tidak hanya di Kecamatan Jonggat, tetapi uga dilaksanakan tiga kecamaan yang merupaan bagian dari KKM MIN 2 Lombok Tengah. 
Yandika Nugraha, Peningkatan Kompetensi Guru...

c. Mengingat betapa pentingnnya pelatihan penguatan materi matematika ini, diharapkan pada masa yang akan datang tetap diadakan pembinaan berkelanjutan dengan mengangkat tema yang berbeda atau tema yang sama.

\section{UCAPAN TERIMA KASIH}

Kegiatan Pengabdian Kepada Masyarakat ini merupakan salah satu bagian dari Tri Dharma Perguruan Tinggi yang harus dilaksanakan oleh civitas akademika khususnya para tenaga pengajar. Salah satu kegiatan yang dilakukan adalah madrasah binaan, termasuk di dalamnya adalah peningkatan kualitas madrasah melalui melalui pelatihan penguatan materi matematika untuk meningkatkan kompetensi guru matematika di Madrasah Ibtidiyah Se-Kecamatan Jonggat Lombok Tengah. Pada hari Sabtu Tanggal 26 Agustus 2017 telah dilaksanakan kegiatan pengabdian yang diberikan kepada sebanyak 20 Guru yang mengajar matematika yang berasal dari perwakilan madrasah ibidaiyah yang tersebar di Kecamatan Jonggat dengan hasil yang cukup baik. Mudah-mudahan hasil kegiatan yang dilakukan ini akan terus berlanjut sesuai dengan tujuan pengabdian kepada masyarakat itu sendiri.

\section{DAFTAR RUJUKAN}

[1] Atmosoeprapto Kisdarto, Produktivitas Aktualisasi Budaya Perusahaan, Jakarta: PT Elex Media Komputindo Kelompok Gramedia, 2000.

[2] Arends, Richard, Learning to Teach, New York: McGraw-Hill Companies, 2001.

[3] Bambrough, J., Training Your Staff, New Delhi: Sterling Publishers, 1998.

[4] Muhibbin Syah, Psikologi Belajar, Jakarta: PT Rajagrafindo Persada, 2006.

[5] Nasution, Didaktik Azas-azas Mengajar, Jakarta: Bumi Aksara, 2000.

[6] Prihandoko, Pemahaman dan Penyajian Konsep Matematika secara benar dan menarik, Jakarta: Dediknas, 2006.

[7] Slameto, Belajar dan Faktor-Faktor Yang Mempengaruhinya, Jakarta: Rineka Cipta, 1995.

[8] Suwangsih dan Tiurlina, Pembelajaran Matematikan, Bandung: UPI press, 2006.

[9] Wina Sanjaya, Strategi Pembelajaran Berorientasi Standar Proses Pendidikan. Jakarta: Prenata Media, 2006. 